\section{INVESTIGATION AND ANALYSIS OF THE INFLUENCE OF SPORTS DANCE BASED ON WIRELESS NETWORK MODE ON COLLEGE STUDENTS' MENTAL HEALTH}

\author{
INVESTIGAÇÃO EANÁLISE DA INFLUÊNCIA DA DANÇA DESPORTIVA BASEADA NO MODO WIRELESS \\ NETWORKNA SAÚDE MENTAL DEESTUDANTES UNIVERSITÁRIOS \\ INVESTIGACIÓN Y ANÁLISIS DE LA INFLUENCIA DE LA DANZA DEPORTIVA EN LA SALUD MENTAL DELOS \\ ESTUDIANTES UNIVERSITARIOS BASADOS EN EL MODELO DERED INALÁMBRICA
}

Jia Qi ${ }^{1}$ (D)
(Public health Education)

1. Xi’an Medical University, Xi’an Shaanxi, 710021, China.

\section{Correspondence:}

Xi an Medical University, Xi'an Shaanxi, 710021,China. olorpo@163.com

\begin{abstract}
Sports dance can not only improve the quality of students, but also affect the healthy psychology of college students. The influence of sports dance on the mental health of college students based on the wireless network mode is investigated and analyzed. The influence of sports dance on students' mental health quality was studied by comparing before and after the experiment. First, based on the characteristics of the wireless network mode, the MQVA algorithm based on the wireless network mode is proposed. Finally, students of two classes are taken as research subjects, and the related indexes of their psychological quality are measured by the algorithm. The survey results show that the overall level of mental health of the subjects is significantly higher than that of ordinary college students and ordinary people. Sports dance has a positive effect on the mental health of college students.

Keywords: Computer Communication Networks; Dancing; Student Health; Mental Health; Influence.

\section{RESUMO}

A dança esportiva pode não só melhorar a qualidade dos alunos, mas também afetar a psicologia saudável de estudantes universitários. A influência da dança esportiva na saúde mental dos estudantes universitários com base no modo de rede sem fio foi investigada e analisada. A influência da dança esportiva na qualidade da saúde mental dos alunos foi estudada através da comparação entre o antes e o depois do experimento. Em primeiro lugar, com base nas características do modo de rede sem fio, propõe-se o algoritmo MQVA baseado no modo de rede sem fio. Finalmente, alunos provenientes de duas turmas são tomados como objeto de pesquisa, e os índices relacionados de sua qualidade psicológica são medidos pelo algoritmo. Os resultados da pesquisa mostram que o nível global de saúde mental dos participantes da pesquisa é significativamente maior do que o dos outros estudantes universitários e pessoas comuns. A dança esportiva tem um efeito positivo na saúde mental dos estudantes universitários.
\end{abstract}

Descritores: Redes de Comunicação de Computadores; dança; Saúde do Estudante; Saúde Mental; Influência.

\section{RESUMEN}

La danza deportiva puede no sólo mejorar la calidad de los alumnos, sino también afectar la psicología saludable de estudiantes universitarios. La influencia de la danza deportiva en la salud mental de los estudiantes universitarios con base en el modo de red inalámbrica fue investigada y analizada. La influencia de la danza deportiva en la calidad de la salud mental de los alumnos fue estudiada por medio de la comparación entre el antes y el después del experimento. En primer lugar, considerando las características del modo de red inalámbrica, se propone el algoritmo MQVA basado en el modo de red inalámbrica. Finalmente, alumnos provenientes de dos grupos son tomados como objeto de pesquisa, y los índices relacionados de su calidad psicológica son medidos por el algoritmo. Los resultados de la investigación muestran que el nivel global de salud mental de los participantes de la investigación es significativamente mayor que el de los otros estudiantes universitarios y personas comunes. La danza deportiva tiene un efecto positivo en la salud mental de los estudiantes universitarios.

Descriptores: Redes de Comunicación de Computadores; Danza; Salud del Estudiante; Salud Mental; Influencia.

\section{INTRODUCTION}

With the progress of mankind and the continuous development of social economy, in twenty-first Century, higher education paid more and more attention to the overall improvement of students' personal qualities. In college education, college students' physical and mental health and artistic quality have become a very important quality. College students' mental health education has become an important part of quality education. ' Under the pressure of heavy schoolwork, economy and interpersonal communication, college students can easily produce psychological barriers and excesses, if they have no healthy psychology. College sports dance education can effectively relieve the pressure of college students, adjust their mood and reduce the emergence of 
extreme mental state. ${ }^{2}$ Therefore, the sports dance curriculum is closely related to the development of College Students' mental health. In order to make the sports dance develop well in our country and move towards the high level of the world, it is particularly important to study the influence of the sports dance course on the psychological health of the college students, to analyze the existing problems and to put forward the improvement measures. As the network information technology is becoming more and more widely used in practice, infinite network technology is used as a kind of network information technology which is rapidly developed and widely used in practice. Because of its relatively low cost in practical application and the advantages of convenience and other features, the application range of wireless network is relatively wide in practice, which brings great convenience to real life. ${ }^{3}$ In recent years, the wireless network model has been widely applied to the study of the influence of sports dance on the mental health of college students.

\section{STATE OF THE ART}

Sports dance, also known as the international standard ballroom dance, includes two items: Standard Dance (Modern Dance) and Latin dance. The standard dance (Modern Dance) includes waltz, Vienna waltz, tango, fox trot and fast dance, while Latin dance includes rumba, Cha, samba, cowboy and bullfight. It is a walking dance competition for men and women. ${ }^{4}$ Each dance has its own dance music, dance steps and styles, and can design different sets of dance movements according to different music and movement requirements. Sports dance in China is a new sports project. Although it has developed late, it has been widely recognized by the society in China, and some scholars have studied the issues related to sports dance. ${ }^{5}$ Some scholars have studied the benefits of participating in sports dance training on human physiological health from a health perspective, and have conducted in-depth discussions on the regulation and promotion of the cardiovascular system of human sports. From the perspective of mental health, sports dance can promote people's mental health. Domestic research on the impact of sports dance on people's mental health has also produced many results. For example, some scholars have studied the influence of sports dance on people in recent years. The results show that after a period of sports dance, more than $70 \%$ of the people feel the mood is stolen and energetic, and their mood is more stable than before. Therefore, the investigation and analysis of the influence of sports dance on College Students' mental health based on wireless network mode has important practical significance.

\section{ANALYSIS AND DISCUSSION}

In the hardware environment of Windows7 of Intel (R) Core (TM) I3 2.4GHz and $2 \mathrm{G}$ memory, the Microsoft Visual $\mathrm{C}++6$ is used as the experimental data mining platform, which is used as a database management system. After eliminating some useless records, the amount of experimental data is 9860 . Before the experiment, considering the inconsistency and incomplete of the experimental data, it is necessary to deal with the data in order to meet the requirements of the mining. The data is preprocessed and analyzed.

In terms of mental health, the changes in mental health of students can be drawn by statistics of mental health standards before and after participating in sports dance. The "mental health standard" cited by this article is proposed by American psychologist Maslow and mis man, which includes 10 questions, including "whether there is sufficient sense of security", "whether there is a goal of life and practical", and "whether to keep in touch with the real environment" After participating in the sports dance, it is known that the experimental group is better than the control group. The ability to learn from experience is better $(P<0.01)$, interpersonal relationship is better $(P<0.01)$, emotional control ability is improved $(P<0.01)$, and it is more able to adapt to the surrounding environment $(P<0.01)$. The study uses the Motivation, Attitude, Behavior, and Cognitive Measurement Scales to have two dimensions of motivation and avoidance motivation. But the two dimensions can also form a general motive. The higher the score, the stronger the motive. The higher the score of the cognitive level, the higher the cognitive level.

In Table 1, the effective value of the three dimensions of sports motivation can be obtained, the mean of participation tendency is over 11, and the avoidance value is far lower than that of the tendency of participation, which means that students are more willing to participate in sports dance movement. The low avoidance tendency indicates that the enthusiasm and initiative are higher, so the total motivation score is more than 15 points. In the table, it can be seen that students of different professional categories also have a certain level of motivation when participating in sports dance sports. According to the characteristics of the profession, it can be said that the professional sports dancers are relatively high in the cognitive level of participating in the sports dance movement, and at the same time, they can have a certain degree of stability, and the self-awareness is gradually formed. In the analysis of the influence of school sports dance on students' attitude and behavior indicators, attitude can be interpreted as the psychological tendency of students to participate in the sports dance movement. Therefore, the change of self-attitude also has some influence on the behavior measures, as shown in Table 2.

From Table 2, after conducting surveys and statistics, it can be seen that the two dimensions of clear goals and timely timeliness in attitudes. The sum of these two dimensions becomes the total amount of attitude. According to different sports levels, the clarity of the goal of the dancers without level and the timeliness of decision-making are mostly at 12 points, which is lower than the average score. However, the attitude of the second-level athletes in the dance program is about 14 points higher than the average. The corresponding attitude affects the behavior. The behavioral standard of the second-level athletes is higher than that of the students without the sports level, and the stability is also high. The curve of the dance action behavior is shown in Figure 1.

As shown in Figure 1, after the corresponding learning of dance action is completed in the training phase, the optimal correspondence is selected according to the accuracy of corresponding relations. The validity of correspondence is verified in the stage of automatic generation of dance movements. In the automatic generation stage of the dance movement, the dance action is generated in the experimental data set using a dance movement corresponding to a specific type of dance, such as social dance. Taking tap dancing and its music as an example, the corresponding correspondence and corresponding accuracy of the training obtained are shown in Figure 2.

Table 1. Statistics of campus sports dance motivation of different majors.

\begin{tabular}{c|c|c|c|c|c|c}
\hline \multirow{2}{*}{ index } & \multicolumn{2}{|c|}{ General group } & \multicolumn{2}{c|}{ Specialties } & \multicolumn{2}{c}{ Training group } \\
\cline { 2 - 7 } & $\mathbf{M}$ & $\mathbf{S D}$ & $\mathbf{M}$ & $\mathbf{S D}$ & $\mathbf{M}$ & SD \\
\hline Participation trend & 11.38 & 2.401 & 11.00 & 3.464 & 12.25 & 3.870 \\
\hline Avoidance tendency & 7.47 & 2.620 & 8.00 & 3.372 & 7.87 & 3.734 \\
\hline motivation & 15.91 & 3.928 & 16.00 & 5.351 & 15.37 & 6.704 \\
\hline Cognition & 25.77 & 5.214 & 27.80 & 6.787 & 28.04 & 8.898 \\
\hline
\end{tabular}

Table 2. Basic statistics of campus dance attitude index for different types of University Students.

\begin{tabular}{c|c|c|c|c|c|c}
\hline \multirow{2}{*}{ index } & \multicolumn{2}{|c|}{ General group } & \multicolumn{2}{c|}{ Specialties } & \multicolumn{2}{c}{ Training group } \\
\cline { 2 - 7 } & $\mathbf{M}$ & $\mathbf{S D}$ & $\mathbf{M}$ & $\mathbf{S D}$ & $\mathbf{M}$ & SD \\
\hline attitude & 26.45 & 4.810 & 24.37 & 5.776 & 28.67 & 4.461 \\
\hline goal clarity & 13.41 & 2.883 & 12.96 & 3.355 & 14.29 & 2.351 \\
\hline Timeliness of decision & 13.04 & 2.637 & 12.42 & 3.033 & 14.38 & 2.851 \\
\hline behavior & 27.45 & 7.939 & 26.60 & 9.291 & 29.83 & 7.284 \\
\hline
\end{tabular}




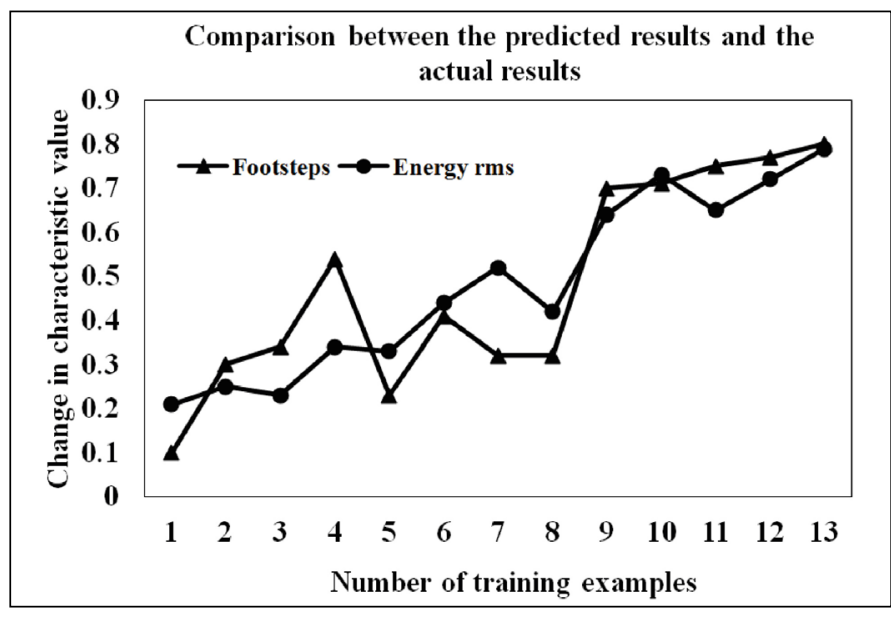

Figure 1. Change in the eigenvalues of foot trajectory and energy rms in tap dancing.

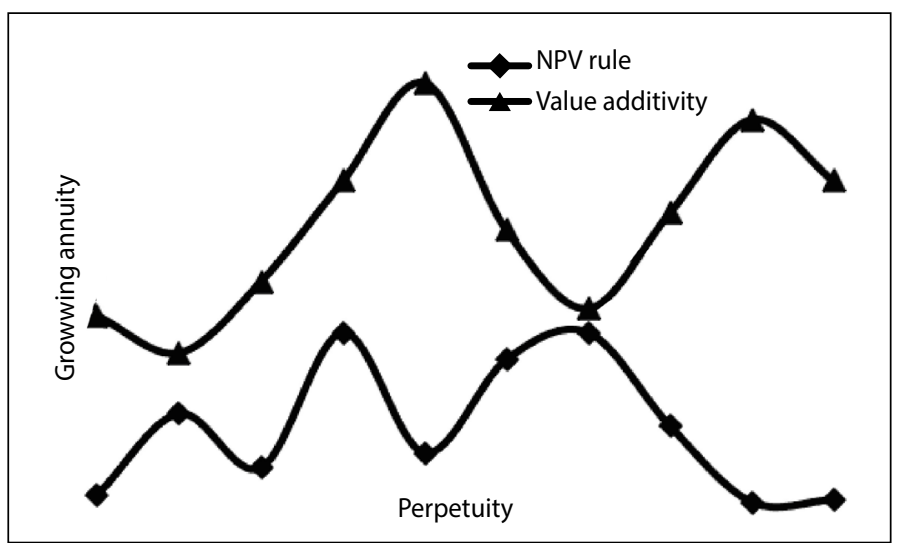

Figure 2. The relationship between the number of matching features and the accuracy of the corresponding relationship.

Finally, the influence of the years of the school sports dance movement on the self-description of the students is discussed. The part uses the body self-description questionnaire (PSDQ). The main direction of this scale is to look at the eleven standards of health, body weight, coordination, athletic ability, physical activity, physical appearance, strength, flexibility, overall body, endurance, and self-esteem. In the survey, to understand the number of years for the participants to participate in sports dance, it can be divided into five cases, which are under one year, two, three, four and five years, respectively. Then compared to the different stickiness, the results of the survey indicated that the longer the duration of the participation is, the more positive the impact of the statement on the body, and the lower the value, on the contrary. But because they are the most studied objects of college sports majors and since the particularity is a long time to participate in all kinds of sports athletes, the ability of these people and sports time is long, the gap in the self-description of the dance is not particularly prominent.

\section{CONCLUSION}

The influence of sports dance on College Students'mental health based on wireless network model is studied. The influence of dance activities on students'sports quality and mental health quality is studied. First of all, 60 students in a university were selected as the experimental subjects, and they were divided into two groups to test their body shape index, body function index and physical quality index before the sports dance movement intervention. After 10 weeks of sports dance, the students of the control group and the experimental group were tested. Finally, the test data before and after the exercise were used to make statistics and analysis by using the SPSS software. Through research, it is concluded that participation in sports dance can promote the healthy development of students' motivation, cognition, attitude and behavior. Sports dance can play a positive role in students' mind and body. According to the research, the sports dance movement is conducive to the physical and mental development of the students. Therefore, in the teaching work, it is necessary to combine the sports to educate the students to promote the students' all-round development.

The author declare no potential conflict of interest related to this article

AUTHORS' CONTRIBUTIONS: The author has completed the writing of the article or the critical review of its knowledge content. This paper can be used as the final draft of the manuscript. Every author has made an important contribution to this manuscript. Jia Qi: writing and execution.

\section{REFERENCES}

1. Cheng W. Study on Influence of Basketball on College Students'Physical and Mental Health. Journal of Changjiang Institute of Technology. 2016,7(1):47-83.

2. Rong T. Study on The Influence of Cell Phone Dependence Intensity on College Students' Physical and Mental Health,Interpersonal Relationship and Learning Efficiency-An Empirical Analysis Based on Investigation of 2240 Colleges in China. Heilongjiang Researches on Higher Education. 2018,2(4):457-632.
3. Yao B. On the Influence of Sports Activities on Mental Health of College Students. Bulletin of Sport Science \& Technology. 2016, 57(9):772-793

4. Gao C, Gao X. Research on the influence of computer network status on college students'mental health RISTI - Revista Iberica de Sistemas e Tecnologias de Informacao. 2016, 20(16):349-361.

5. Zheng HY. Research on the Influences of Taijiquan Training for Female College Students Physical and Mental Health. Journal of Heilongjiang Vocational Institute of Ecological Engineering. 2017,5(3):85-103. 